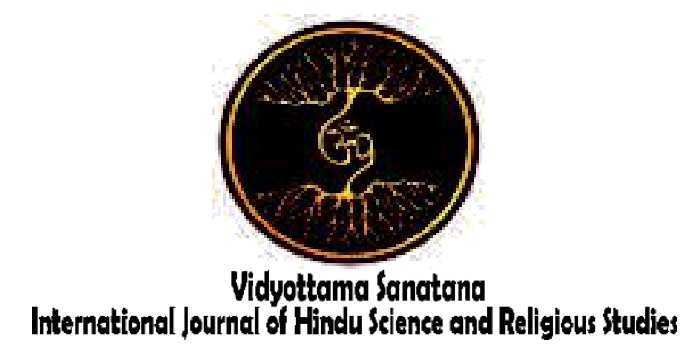

Vol. 2 No. 1 May 2018

\title{
Religion In The Adolescents' Point Of View: The subjectivism perspective by søren a. Kierkegaard
}

\author{
By: \\ Marsono \\ Institut Hindu Dharma Negeri Denpasar \\ E-mail: marsono.65.19@gmail.com
}

\begin{abstract}
The specific characteristic of the adolescents is their existential. It means that the adolescent's involvement in term of thought and their era's situation are closely related to the development of the adolescence itself in the transition from childhood to adolescence. In this transition process, the adolescents have to be able to put their existence between the social transformation and the demand to be mature which come from their social environment. This perspective makes them to be something that is interested to be discussed. This writing will try to give a kind of description about the involvement of adolescents in reading and interpreting their religions in the point of view of Søren Kierkegaard's subjectivism. The discussion will focus on the diversity elements of the adolescents which are closely related to the subjectivity. This aims to describe the characteristics and intensity of the diversity's struggle faced by the adolescents which is more existential.
\end{abstract}

Keywords: religion, adolescents, subjectivism

\section{Introduction}

Along the history, the adolescents are commonly identified with the characteristics of seeking and anxious and also tense. The mixed characteristics of the adolescents today's life in certain situation, create a kind of internal flame which is quiet significant. This emerges both in the thought level and the life's aspects. Based on this characteristic, the adolescents are not merely limited by certain 
limitation of age range but it is more focus on specific characteristics.

This research is a kind of qualitative research named library research which used versten method in the data collection. This study focused on the tendency of adolescent in viewing religion and use Søren Kierkegaard's subjectivism point of view. The discussion includes several tendencies which become the discussion topic by the adolescents, it is about the formation euphoria which affect the freedom and the effect of globalization that make the transformation's current become unpredictable and shaking.

\section{Discussion}

\subsection{Subjectivism by Søren Kieregaard}

Søren Aabey Kierkegaard is the full name of this Denmark's philosopher and the one who is called as "the father of existentialism" . Kieregaard was born on November $5^{\text {th }}, 1813$ in Copenhagen and passed away on November $11^{\text {th }}, 1855$. These two important events of his life happened in Copenhagen. Kieregaard was born as the last child from 7 siblings in his family. When he was born, his father ( Michael Pederson Kieeregaard) was 56 years old and his mother Anne Lund was 45 years old. His family was belong to one of noble families in Copenhagen (Hasan,2014:139).

There are two main points which were delivered by Kierkegaard in his article entitled: Truth is Subjective" (Pieterson, 1996: 80-84). In that article, Søren Kierkegaard emphasized on how the truth of religion are subjective and personal. Despite of denying the existence of the differences between truth and lie, but he was insisted that objective approach did not suite to be used to solve the problems related to the religions. In religion matters, Kierkegaard explained that the most important thing is someone's way to relate him to the truth (religion) that he believes to be true. The unique thing was, Kierkegaard emphasized that to have a belief (religious) someone does not need to be able to prove that what they believe is true.

First of all, Kierkegaard explains the difference between objective and subjective reflection. A subjective reflection enters the inner strength of an individual. On the other hand the top of the individual's inner strength is passion. Because of that, the subjective truth is a paradoxical. This paradoxical comes from the boundary between the truth and the existential subject (individual). Furthermore, objective reflection is an effort to perceive the truth objectively. Objective reflection does not focus on the relationship between the truth and individual, but on the question whether the matter is a truth that in known by the individual. Related to those two reflections, Kierkegaard gives an example of the God's existence:

"Objectively, reflection is directed to the problem whether this object is the true God; Subjectively, reflection is directed to the question whether the individual is related to a something in such manner that this relationship is in truth a God-relationship" (Peterson et.al, 1996: 81).

Kierkegaard also gives an emphasize that to understand the truth about God and faith, those two reflections (subjective and objective) cannot be applied together. As it was agreed that an existential individual is the same as the individual which is exist and someone cannot be exist in two places at the same time. If it is forced to be so, when someone is about to be in the two places at the 
same time, it means that they are in their passion, and passion is the highest expression of subjectivity. As it is revealed by Kierkegaard in his article:

When he is nearest to being in two places at the same time he is in passion; but passion is momentary, and passion is also the highest expression of subjectivity'(Peterson et al., 1996: 81).

Because of that, Kierkegaard give his opinion that God can only be existed in someone's inner as a subjective point of view. Bringing God in to objective point of view is something impossible. As God is a subject and the only one that match the subjectivity in human's inner.

The existing individual who chooses to pursue the objective way anters upon an entire approximation process by which it is proposed to bring God to liht objectively. But this is in all eternity impossible, because God is a subject, and therefore exists only for subjectivity in inwardness" (Peterson et al., 1996: 81).

There must be differences between objective and subjective knowledge as there is difference between the knowledge which is obtained from experiencing and the one that is obtained from observation only. Kierkegaard differentiates the objective and subjective knowledge related to passion. The objective knowledge is apart from the passion therefore subjective knowledge is closely related to passion in individual's inner. Regarding to this, which knowledge is the most useful one to be used to approach the truth of God? Kierkegaard gives two examples; first, when someone goes to the church with objectivity concept about God which is true in his mind and prays without any passion or second, someone who prays sincerely with his passion, belief and his prayer is strengthened by his belief upon an object that he believes as God. From those examples, which one has the highest truth value?

The subjective and objective matters are also related to "what" and "how" something is revealed. The perception on objectivity tends to be focused on "what" is discussed. Furthermore, the perception on subjectivity focuses on "why" something is revealed. What is content based is true, it can be wrong as if it is in certain people mouth (or revealed in certain way). The term "how" in this context is not related to the attitude, expression, and others, therefore it is related to the relationship between individual as a creature that has an existence with all things which he wants to be revealed. The objective point of view is more focused on what is in the mind, while subjectivity tends to be focused on the inner belief of an individual. In the religious context, the existence of belief in a religion makes a religion objectively true, in fact the subjective belief makes the religion to be a truth. Because of that, Kierkegaard reveals briefly that subjective "how" will form the truth. As he explains in his article:

At its maximum this inward "how" is the passion of the infinite and the passion of the infinite is the truth. But the passion of the infinite is precisely subjectivity and thus subjectivity becomes the truth" (Peterson, 1996: 83).

In his article, Kierkegaard gives the definition on the truth as follow:

An objective uncertainty held fast in an appropriation process of the most passionate inwardness is the truth, the highest 
truth attainable for an existing individual" (Peterson et al, 1996: 83).

The uncertainty objective emerges as subjectivity has its uncertainty. The truth is when the individual chooses to accept the uncertainty of the objective in his passion of eternity. As it is stated by Kierkegaard, when the individual think about this universe and wish to find the God, so he finds the"kemahakuasaan" (the one and only) and wisdom, therefore he also face a lot of things that may distract his mind and emerges anxiety. The blending of these matters are the one that is called the objective uncertainty by Kierkegaard.

In his last article, Kierkegaard concludes that if the individual is able to hold God objectively. So he will not be able to believe in God. In the other hand, as he cannot do it (holding God), so he has to believe the existence of God. When he wishes to protect their faith inside his self, so he has to constantly hold the uncertainty of that objective (related to the existence of God).

"If I am capable of grasping God objectively, I do not believe, but precisely because I cannot do this I must believe. If I wish to preserve myself in faith, I must constantly be intent up on holding fast the objective uncertainty" (Peterson et al, 1996: 84).

Humans are decision maker in their existence, whatever their decision, it never be fixed and perfect. Kierkegaard stated:

Yes, I perceive that there are two possibilities, one can do either this or that." (Hassan, 2014: 151).

Humans will be always faced the choices. However, the first choice has to be decided with a kind of consideration of which one is better and which one is worse thus the decision will be meaningful. Furthermore, all his actions are supported by an ethical attitude which cannot be separated from the responsibility so this individual, according to Kierkegaard, has goes through an existence in aesthetic level. This aesthetic has to be upgraded to the higher level, to the ethical level. The esthetic values transfigurations to the ethical level make it possible to make those values last forever. The ethical phase is a transitional phase; it is a transition to the higher phase. The last phase that has to be achieved by humans is the religious phase. In this phase, humans are not expecting the understanding and witnesses from other humans anymore. In this religious phase, humans perform their true identity that is as single human, face the God. The meeting with God as a dialogue ( Hassan, 2014: 152-153).

In the aesthetic level of existence, the individual lives in a strong tendency to fulfill all their happiness and sensuality pleasant. Aesthetic individual tends to give up on his inner motivation to gained kind of sensual pleasant and always try to avoid the pain and boredom. He will always try strongly to find the happiness and pleasant in many variation. An attitude that appears in this phase is "enjoy the life" and expresses it; enjoy yourselves; in that pleasant you can enjoy yourselves." (Kierkegaard,1986: 185)

The existence in ethical level is signed by the awareness of individual on the importance of universal norms and values toward the peacefulness of life. Those universal norms and values must be obeyed so the individuals should manage their lives in the line with those norms and values. Ethical humans believe that meaningful life is to live based on the universal values and regulations. Based on that, an individual always states his 
personal choice and commitment to respect obey and maintain his responsibility and also the universal regulations. For him, sacrifices himself to do anything which becomes his responsibilities and universal regulation are the expression of human's real quality ( Kierkegaard, 1986:187).

Both aesthetic and ethical phases of existence end in desperation. According to Kierkegaard, if the decision is based on the awareness of each individual, the way to understand the religious dimension will be opened. Simply, it can be said that the decision awareness makes the individual aware that he can count on himself and his strength. The individual thinks that he is small and weak while wishing for the support and help from non-human power. This nonhuman power refers to the God Himself. God becomes the center to whom the individual hands himself and it is unconditionally. This unconditional delivery is based on the belief that the God is the last place to go and gives the security to humans. Kierkegaard stated that "as the body is in healthy situation and free from the decision if only, precisely in the decision, that individual count on God transparently" (Kierkegaard, 2986:187).

\subsection{The Discussion Field of the Adolescents}

In 90s decade, is the time that marked the emerged of diversity spirit of Moslem in Indonesia. In the massive level, there are some social phenomena that showed that the diversity of religious life in this country was getting livelier. Although most of them happened in symbolic level, that tendency has to be observed as they can emerge some important instruments which influence the religious lives.
The permission of using religion attributes at schools for instance, relatively it becomes the sight that all the sides of religious lives of students is getting closer. Previously, the character of "Orde Baru" government that was very powerful towards all social power including; religion, that power tended to be confrontative, so since the beginning of the $90 \mathrm{~s}$ decade there was positive tendency. The country started to approach and embrace the sector of religion power in the society. These events unconsciously gave birth to the effect and strong foundation to emerge the religion matter in wider area. This means that, if previously the propagation of these religious matters was extremely difficult as there was tendency that the country minimalized the effect of religion toward the life of having a country, so in the following it seems to be a kind of media that introduced the discussion and also the practice related to religions in the society.

However, there was one thing needed to take into account "accommodation" of the country toward the religion power in $90 \mathrm{~s}$ decade was not happened in one way. Beside the "conspirative" explanation toward these phenomena- that the military groups were difficult to be asked to work together, there was the other social process which went after the new tendency to the new religion. This was as the effect of Orde Baru policies which become kind intellectual infestation media for the young religious people. The development, especially in educational and economical field, has emerged the middle class with religious background. The emergence of this middle class of Muslim tends to be limited as "modernist" group only. Recently, it has 
widened, so it can involved the "traditionalist" group.

The main change accumulation especially the one that involves the adolescent seems very clear as the reformation's gong is sounded. Reformation itself basically opens the freedom of expression, thus the idea which is previously judged as taboo become something that is common to be discussed recently. At that time the religious and appreciation passion towards the religion's sides get stronger. Moreover, the existence of that kind of spirit is supported by the attitude and the wish to involve the role of religion in the process of social changing which massively happened in every side of life.

Following the current of changing and the train of reformation that walk slowly, the young religionists involve in some politic discussion. The themes in the discussion are closely related to the contextual situation; pluralism, civil society, syariah formalization, etc. those discussions do not always involve the individuals (the young people), but also involve certain communities.

\subsection{Globalization and Aesthetic of Religion}

Beyond those sociologic processes, there also the other changing process that signed that the globalization influence is getting stronger. In this case, the technology invention becomes a kind of cause towards some life styles of the society thus it cannot be denied that it causes some new tendencies in the society life's order.

According to Giddens (1999), globalization cannot only be understood as the economical phenomena, as it involves transformation process of space and time. The technology invention, especially information technology ( computer, internet, mobile phone, etc) which is followed by massive communication intensity in global level, that make it possible for humans to do a mean of communication called action at distance. The emergence of several new patterns of relationship in economy, social, politic, communication, daily attitude pattern, and also in the relationship among individuals. On the other hand, globalization has enters its ideas to some local variety such as; nationstate, tradition, relationship pattern in the family, or relationship pattern among countries, in this case, the local strength such as religion is faced by a big matter called globalization, which make this world hectic, risky, and unpredictable.

Under this kind of circumstance, the aesthetical process of life happened; it means that the tendency of life as aesthetic process is getting stronger. The products which are consumed are not merely seen from their function, but from their symbol related to identity and status. When this tendency happens, the life's essence become not important as the life's aesthetic has its beauty meaning so what is been seen from that kind of life is image. In this process, it can be seen the process of life has been moved from ethical to aesthetical. This movement is not only show the sign from the basic life's changing but also as a sign from the formation of different life's ethos thus the consumptive (symbolic) ethos is more important than productive ethos. Moreover, religion becomes a product that is consumed. (Abdullah, 2006: 114-115).

This phenomenon is something disappointing in Kierkegaard's terminology, as religion matters in modern context have been trough the opposite process. Religion matters are expected to achieve religious 
process, but individual's quality in his religion has decreased from ethical process to aesthetical process. In this point, religion is the work of art then it becomes private business. This is in the line with the diversity ideology which is emphasized by the globalization process where religion privatization tendency is a logical consequence from the general one.

Religion privatization in the relation of the work of art is not merely the signed that religion is getting apart from the public importance, but it show that societies' tendency in questioning the religion, it is related to what religion has done for its followers. Religion, as it is stated by Beyer ( 1991: 377), has to be able to give service not only support and increase their belief toward the religion itself, but also in widening the implication of religion beyond that religion field itself. Furthermore, religion does not only emphasize its function but its performance in giving solution beyond its problems.

\subsection{The Subjective Space of Adolescents' Diversity}

The diversity dimension that is quite important for the adolescent is subjectiveexistential personal dimension. As it has been revealed above that is no other than manifestation of the adolescents' personal faith. The subjectivity space based on the writer's point of view is quiet significant for the process of religion socialization in providing and guiding the social role of the adolescents. In Muslim's context and the structure of the religion itself, this subjective space (belief) is stated as something "relative". This is because, according to Kierkegaard, the faith is only existed in an individual's subjectivity point of view, thus the truth becomes subjective and personal (Kierkegaard, 1996:80-81).

This faith intensity is in the line with the complexity of life's variables, thus at the end influents someone's faith; the family education, local culture, social-politic affiliation or the current meeting of culture and individual and culture diversity (global context). In this subjective space, the adolescents define several religion taught.

The relativity which they are keen on is not far from responsibility, it contains a more dynamic meaning; it refers to the spirituality of someone's inner which give themselves to the God and accept the responsibilities personally. Based on this assumption, the young religionists along the history, struggle to interpret several treasures and the religion thought. The anxiety and concerned complete their basic responsibility, when the young religionist realized that some aspects of religion are no longer worked to face the societies' problem. In this point, they do a kind of reread towards their tradition critically.

Ahmad Wahid, is a popular figure which is able to describe the struggles of adolescents in rereading their religion lesson, they can be arrived on a very critical point such as: too liberal, with the logic interpretation which stab the religion's heart. This young man who comes from Madura did not only go out from the traditions diversity of Madura in general but he was able to emerge the thought of diversity which is full of goodness in his era (Sumarthana, 1981:8286).

However, in this kind of personal existential, the struggle will keep going on. Religion in daily understanding of an 
individual sometimes look like voting process, it is unstoppable, involving the past, nowadays, and the future. Furthermore, the starting point of those experiences, according to Kierkegaard is humans, humans as subjective fact (Hasan, 2014: 151). Then, they are reminded that this is the tome to make decision over several choices. Kierkegaard states "concentrated in one single proposition, I say merely either/or".

At the same time, the subjectivity space of adolescents' diversity is in the shadow of religion education influence which tends to be mechanical. In that kind of situation, they try hard to understand the religion matter which is more interpretative. In the writer's opinion, it is the decision regarding the subjective religion space that influences the tendency of the adolescent religious matters. This group of personal experience quickly or slowly will form the discursive points and interferential relationship which lead them to be in certain religion at the end. The discursive characteristic according to Michael Foucault is in inter-reverential pattern, sometimes is not realized to be good because of the diversity and its elements. However, the important thing is that the one who gives this discursive point a relative statement, thus the space which is filled buy the speaker of the statement according to Foucault looks like an empty space which can be filled with whoever with good competency ( Faucault, 1972: 92).

As the influence of conventional religion organizations are getting vanished, the referential subjective web of diversitywhich existed during the transition era is filled with several objective dimensions by several objective dimensions of society (social, politic, economy, culture which follows the globalization, it can be easily lead the diversity of adolescent to the uncontrollable condition. Psychologically, this can decrease the awareness of the adolescents into the two extreme point in religion; fundamentalism and liberalism.

In relation to this subjective dimension of adolescents' diversity, thus the most urgent agenda to be decided is how these structure and socializing system of these religion values running, whether it is in formal or informal level. In formal level, the agenda that should be done is developing the education format on the religion values which direct to the faith communication form to accommodate the particular wealthy of the adolescent. Here, a rich method and approach are needed which in the line with the development of science and knowledge. The meeting of several kinds of science disciplines cannot be avoided anymore, especially to sharpen the objective dimension of religion lesson.

The thing that needs to be taken into account in this process is all the thinking tendencies of the young religionists have to be in a good dialogue process. This aim is to minimalize the exclusion process toward the diversity of adolescents' religious experience in this complex situation. Furthermore, this also means that every group has to own sensitivity toward the diversity of subjective dimension of religion, whether it is social and cultural.

\section{Conclusion}

The adolescents' struggle in understanding their religion has been explained above, especially from the subjective side, it has to be acknowledged it cannot represent all the fluctuation in general. 
This exposition may be only happened between the group of adolescent which are really struggle among the diversity which they inherited and also the complexity of the globalization. On the other side, the other group of adolescent, in different intensity, they not only follow the other group, therefore, they are drifted away in the globalization current which is dazzling.

Observing this, the writer states his opinion that the subjective space of the adolescents' diversity become more significant to influent their lives' choice. Their religion tendency often follows the life style of this globalization era with some popular culture as its based it is read uncritically. In this domain the young religionist systematically able to find the way out by restudying the essential part of the religion and especially to reuse the Muslim intellectual heritage which is mostly disappear in this globalization.

The informal level of the subjective dimension of adolescents' diversity is the existential of the experience in interacting and interpreting their beliefs. In this matter, the society needs to provide a healthy public place so that the social interaction process is free from the trauma of the history which can eliminate the adolescents' awareness to the (complexity) of social reality that they face.

\section{References}

Abdullah, Irwan, 2006, Konstruksi dan Reproduksi Kebudayaan, Pustaka Pelajar, Yogyakarta.

Beyer, Peter F., 1991, "Privatization and the Public Influence of Religion in Global Society, dalam Mike Featherstone (ed.), Global Culture: Nationalism,
Globalization and Modernity,

Sage Publications, London.

Giddens, Anthony, 1999, Runaway World:

How Globalisation is Reshaping

Our Lives, Profile Books, London.

Hassan, Fuad, 2014, Psikologi-Kita dan Eksistensialisme: Pengantar Filsafat Barat, Berkenalan dengan Eksistensialisme, Kita dan Kami, Komunitas Bambu, Depok.

Kierkegaard, Søren, 1986, Either/Or, vol. I and II, translated by George L. Strengren, Harper and Row Publisher, New York.

1996, "Truth is

Subjectivity", dalam Michael Peterson, dkk. (ed.), Philosophy of Religion: Selected Readings, Oxford University Press, New York.

Kiriana, I. N. (2017). Ngaben Conception In Lontar Siwa Tattwa Purana. Vidyottama Sanatana: International Journal of Hindu Science and Religious Studies, 1(2), 84-92.

Marshall G.S. Hodgson, Marshall G.S., 1974, The Venture of Islam: Conscience and History in a World Civilization, The University of Chicago Press, Chicago.

Mahardika, I. G. N. A. W. (2017). Teaching Hinduism For The Blinds: A Study On Hinduism Teaching And Learning In SLB A Negeri Denpasar. Vidyottama Sanatana: International Journal of Hindu Science and Religious Studies, 1(1), 70-76. 
McGurgan, S. (2017). Using The Culture Of Childhood To Facilitate Compassionate, Student Centered And Holistic Education. Vidyottama Sanatana: International Journal of Hindu Science and Religious Studies, 1(1), 21-29.

Michel Foucaull, 1972, The Archaeolog of Knowledge and The Discourse on Language, Pantheon Books, New York.

Sudarsana, I. K. (2018). IMPLEMENTASI PENDIDIKAN INFORMAL HINDU DALAM MENJAGA POLA KOMUNIKASI REMAJA PADA PERGAULAN SEHARIHARI. Jurnal Komunikasi, 12(1), 40-50.

Sudiani, N. N. (2017). Pedanda Baka Story As Media Of Character Education Since Early Childhood. Vidyottama Sanatana: International Journal of Hindu Science and Religious Studies, 1(1), 61-68.

Sugiharta, I. P. S. O., \& Sudarsana, I. K. (2017). Hypnotic Learning Characteristics On Sisya Brahmakunta Community In Denpasar. Vidyottama Sanatana: International Journal of Hindu Science and Religious Studies, 1(2), 132-145.

Sumarthana, Th., 1981, Ikhtiar Ahmad Wahib: Sebuah Corak Reformasi dalam Islam, dimuat di Prisma, No.8/Th. V Agustus.
Warsana, I. N. (2017). Pattern Of Adolescent Learning Hindu Scholarship Recruits Through Pasraman Widya Dharma Saraswati. Vidyottama Sanatana: International Journal of Hindu Science and Religious Studies, 1(2), 168-178. 